\title{
Resenha
}

\section{A SOLIDÃO DOS MORIBUNDOS: SEGUIDO DE ENVELHECER E MORRER: ALGUNS PROBLEMAS SOCIOLÓGICOS}

\author{
THE LONELINESS OF THE DYING: POSTSCRIPT AGEING AND DYING: SOME
}

SOCIOLOGICAL PROBLEMS

Lourdes Del Giudice Borges ${ }^{1}$

Norbert Elias (1897 - 1990), alemão de origem judaica, sociólogo de formação, é um dos principais representantes da Sociologia contemporânea. Foi um importante pensador social do século XX, tendo sua obra um incontestável valor. O autor teve diversas obras publicadas em português, tais como: Os Alemães (1997); Os estabelecidos e os outsiders (2000); Mozart: Sociologia de um gênio (1995); Norbert Elias por ele mesmo (2001); Sobre o tempo (1998); A sociedade de corte (2001) e A solidão dos moribundos (2001). O autor publicou ainda a obra denominada $O$ processo Civilizador em dois volumes (1990, 1993), no primeiro volume o autor analisa a história dos costumes e no segundo volume volta sua análise para a formação do estado e a civilização.

O livro de Norbert Elias denominado "A solidão dos moribundos” seguido de "Envelhecer e morrer: alguns problemas sociológicos" analisa e discute a dificuldade do ser humano em enfrentar a finitude da vida. O autor analisa ainda como uma sociedade avançada comporta-se diante da morte, bem como os dilemas vividos com relação a encará-la como realidade e as atitudes com relação aos outros e a si mesmo. Elias, ao longo da obra, assinala que "na verdade, não é a morte, mas o conhecimento da morte que cria problemas para os seres humanos" (ibid., p. 11). Elias afirma que é a consciência da morte que traz problemas para os seres humanos, a decadência biológica e a relação com o que tem e traz à vida. $\mathrm{O}$ autor assinala que "experiências e fantasias da primeira infância desempenham papel considerável na maneira como as pessoas enfrentam o conhecimento de sua morte próxima" (ibid., 16). Ao longo do texto, assinala as perspectivas

\footnotetext{
${ }^{1}$ Assistente social pela Pontifícia Universidade Católica de Campinas, especialista em Serviço Social e Pediatria pela Faculdade de Ciências Médicas da Universidade Estadual de Campinas, UNICAMP. Serv. Soc. \& Saúde, Campinas, SP v.14, n.1(19), p. 119-122, jan./jun. 2015 ISSN 1676-6806
} 
analíticas de diferentes épocas históricas em face da morte. Pondera ainda sobre o que leva à solidão dos moribundos, enfatizando a íntima relação entre essa solidão e as transformações decorrentes do desenvolvimento social (ibid., p.12).

Elias afirma que, no estágio atual no qual se encontram nossas sociedades, onde está presente uma expectativa de vida maior havendo uma tendência para o esquecimento da morte no decorrer dos dias vividos. Segundo o autor, na atualidade, a "morte é recalcada" (ibid., p. 15). Ancorado em análise sociológica sobre a experiência da morte ao longo dos séculos e no conceito de Freud sobre recalcamento o autor analisa esse processo ativo no qual o indivíduo tenta manter suas emoções, desejos, tudo aquilo que é passível de entrar em conflito consigo mesmo ou com o mundo, ao nível do inconsciente, mas regido pela interdependência com a sociedade em que vivem, influenciando e sendo influenciado ao mesmo tempo. Segundo o autor, a característica marcante da sociedade moderna consiste no alto grau de individualização, na ampla e "constante contenção de todos os impulsos instintivos e emocionais fortes e uma tendência ao isolamento" (ibid, p. 67). Para o autor há "um constrangimento diante da finitude da vida, que separa tanto os vivos dos moribundos quanto estes dos vivos" (ibid., p. 67).

Elias reconhece que na história da humanidade, esconder a morte da consciência sempre esteve presente, porém os mecanismos mudaram. Atualmente os avanços científicos e tecnológicos que tem permitido o prolongamento da vida e a possibilidade de terceirizar os cuidados com os velhos e moribundos, são as formas mais comuns para encobrir o processo de envelhecer e morrer. $\mathrm{O}$ autor assinala, inúmeros temores que envolvem o fato de envelhecer e morrer, bem como destaca o constrangimento social e o desalento que frequentemente cercam a esfera da morte e que não tem levado a mudanças de atitudes frente à questão. Segundo sua análise, a forma de assegurar às pessoas maneira natural e serena de morrer ainda está por ser descoberta, mas existem alguns meios para se mudar a atitude frente à morte: a amizade e a solidariedade dos vivos e o "sentimento dos moribundos de que não causam embaraço aos vivos" (ibid., p. 76). O autor ao final de sua análise assinala que a morte "não tem segredos. Não abre portas. É o fim de uma pessoa. O que sobrevive é o que ela ou ele deram às outras pessoas, o que permanece nas memórias alheias" (ibid., p. 77). 
No texto Envelhecer e morrer: alguns problemas sociológicos (p.79-104) o autor discute a dificuldade das pessoas frente ao envelhecimento do outro, afirma o autor que as pessoas "não podem imaginar a situação em que suas próprias pernas e tronco deixam de obedecer a sua vontade" (ibid., p. 79). Segundo o autor, "o poder e o status das pessoas mudam rápida ou lentamente, mais cedo ou mais tarde, quando elas chegam aos sessenta, aos setenta, oitenta ou noventa anos" (ibid., p. 83). Afirma ainda que "muitos asilos são, [...] desertos de solidão" (ibid., p. 86).

Nessa obra, o autor discute em profundidade a natureza especial da morte nas sociedades industriais desenvolvidas, assinalando "o isolamento emocional como uma das características preeminentes" que surge "de modo particularmente claro se compararmos os procedimentos e atitudes relativos à morte nas sociedades em estágios mais avançados aos dos países menos desenvolvidos" (ibid, p. 86).

Nesta perspectiva analítica, o autor ressalta que o "estoque de conhecimentos da sociedade em relação aos aspectos biológicos do envelhecimento e da morte aumentou muito nos últimos dois séculos" (ibid., p. 89), tornando-se mais fundamentado e realista. Contudo assinala que "o que é decisivo é o conhecimento não dogmático do que é benigno e do que é maligno na natureza" (ibid., p. 95). Não somente conhecimento biológico com seus avanços, mas o conhecimento da pessoa humana, o ramo do conhecimento onde os problemas discutidos nesta obra estão inseridos.

$\mathrm{O}$ autor instiga o leitor a refletir ao chamar a atenção sobre questões vividas pelo ser humano em relação a morte, a interdependência vivida entre o indivíduo e a sociedade onde se está inserido, o quanto podem influenciar de forma substancial o sentido da vida para os que envelhecem e para os que estão morrendo. O conhecimento da pessoa humana em seu contexto individual e social traz significados surpreendentes para que se possa compreender a finitude da vida com solidariedade, afeto e cuidado real. Assinala que na atualidade, "o cuidado com as pessoas às vezes fica muito defasado em relação ao cuidado com seus órgãos" (ibid., p. 103).

\section{REFERÊNCIAS}

ELIAS, N. A solidão dos moribundos, seguido de Envelhecer e morrer: alguns problemas sociológicos. Tradução Plínio Dentzien. Rio de Janeiro: Jorge Zahar Ed., 2001. 
Serv. Soc. \& Saúde, Campinas, SP v. 14, n. 1 (19), p. 119-122, jan.jun. 2015 ISSN 1676-6806 